\title{
Enhanced Model For Evaluating Information System Success: Determining Critical Criteria
}

\author{
Ansar Daghouri \\ ENSET of Mohammedia \\ University Hassan II of Casablanca \\ Casablanca, Morocco \\ dagh.ansar@gmail.com
}

\author{
Khalifa Mansouri \\ ENSET of Mohammedia \\ University Hassan II of Casablanca \\ Casablanca, Morocco \\ khmansouri@hotmail.com
}

\author{
Mohammed Qbadou \\ ENSET of Mohammedia \\ University Hassan II of Casablanca \\ Casablanca, Morocco \\ qbmedn7@gmail.com
}

\begin{abstract}
The purpose of this study is to enhance the DeLone and McLean information system success by adding a SERVQUAL instrument to evaluate the service quality dimension. An integrated model for evaluating the information system has been proposed. One of the most popular multi criteria decision making techniques, namely AHP was used to determine the weights of each criterion and sub-criterion of the model in order to identify the most influential criterion on information system's evaluation. System quality dimension has a strong influence on information system success $(0.39)$ followed by information quality $(0.22)$. The proposed model could be used to enhance information system performance evaluation.
\end{abstract}

Keywords-Delone \& McLean information system success model;SERVQUAl; multicriteria decision making; AHP method; criteria

\section{INTRODUCTION}

Many definitions are given to define the information system (IS). In [1], author considers IS as an organized set of resources: hardware, software, personnel, data, procedures etc. to acquire, process, store information (in the form of data, texts, images, sounds, etc.) within and between organizations. There are many frameworks and models to evaluate IS success. The most common issue is the choice of right and appropriate factors and assessing them. In the current work, we seek to propose a new model to evaluate information system success based on the model presented in [2] and the SERVQUAL instrument presented in [3]. An integrated model was generated and its criteria and sub-criteria were chosen from previous studies. Analytical hierarch process (AHP) method [4] was applied to select the most influent criteria and sub-criteria on information system success. A sample of one hundred participants expressed their opinions about the importance of each proposed criterion via an online tool. The results show that participants believe that the system quality dimension has the highest impact on IS success $(56.70 \%$ strongly agreed and $27.40 \%$ agreed).

\section{INFORMATION SYSTEMS' EVALUATION MODELS}

This work is based on two main research models: information system success model [2] which is a reference in the field of IS evaluation and SERVQUAL model [3] widely developed and used in the last years. In this section, we will present an overview of the most used models:

\section{A. Information System Success Model}

Authors in [5] conducted a large review of IS success literature to present a new model that consists of six variables and the interdependencies between them. They proposed a multidimensional model that recognizes the success as a process assessed by: system quality, information quality, system usage, use satisfaction, individual impact and organizational impact. In [2] they made three main changes based on the critics of those who have tested the initial model: the addition of a technical variable "service quality" mentioned in [6], the decomposition of the variable "system use" into two variables "intention to use" and "use" referring to the theory of reasoned action [7], the technology acceptance model [8] and the grouping of individual and organizational impacts under a "net benefits" variable.

\section{B. The SERVQUAL Model}

Authors in [9] developed a model designed to measure service quality by capturing respondents' expectations and perceptions along with the dimensions of service quality. The SERVQUAL model was made of ten dimensions of service quality when created but later on, these dimensions were reduced to five because some dimensions were overlapping (Table. I)

TABLE I. SUMMARY OF SERVQUAL ITEMS $[3,10]$

\begin{tabular}{|c|c|}
\hline Dimensions & $\begin{array}{r}\text { Definition } \\
\end{array}$ \\
\hline Reliability & $\begin{array}{l}\text { The ability to perform the promised service } \\
\text { dependably and accurately }\end{array}$ \\
\hline Assurance & $\begin{array}{l}\text { The knowledge and courtesy of employees and their } \\
\text { ability to convey trust and confidence }\end{array}$ \\
\hline Tangibles & $\begin{array}{l}\text { The appearance of physical facilities, equipment, } \\
\text { personnel and communication materials }\end{array}$ \\
\hline Empathy & $\begin{array}{l}\text { The provision of caring, individualized attention to } \\
\text { customers }\end{array}$ \\
\hline Responsiveness & $\begin{array}{l}\text { The willingness to help customers and to provide } \\
\text { prompt service }\end{array}$ \\
\hline
\end{tabular}

\section{MCDM METHODS}

Multiple criteria decision making (MCDM) or multiplecriteria decision analysis (MCDA) [11] is a sub-discipline of 
operation research that explicitly evaluates multiple conflicting criteria in decision making. It is concerned with designing mathematical and computational tools to support the subjective evaluation of a finite number of decision alternatives under a finite number of performance criteria and sub-criteria [12]. The base of all MCDM methods is a decision table. According to [13] for a problem with $\mathrm{M}$ criteria (C) and $\mathrm{N}$ alternatives (A), the decision table will be drawn as showed in Table II while $a_{m * n}$ is the score of alternative $\mathrm{n}$ related to criteria $\mathrm{m}$.

TABLE II. DECISION TABLE

\begin{tabular}{|r|r|r|r|r|}
\hline & $A_{1}$ & $A_{2}$ & $\ldots$ & $A_{n}$ \\
\hline$C_{1}$ & $a_{11}$ & $a_{12}$ & $\ldots$ & $a_{1 n}$ \\
\hline$C_{2}$ & $a_{21}$ & $\ldots$ & $\ldots$ & $\ldots$ \\
\hline$\ldots$ & $\ldots$ & $\ldots$ & $\ldots$ & $\ldots$ \\
\hline$C_{m}$ & $a_{m 1}$ & $\ldots$ & $\ldots$ & $a_{m n}$ \\
\hline
\end{tabular}

Many different types of MCDM methods are referred, the most popular of them are AHP, ANP, ELECTRE, GP, MACBETH, MAUT, MAVT [11, 14]. In this research, the AHP method was used to determine the IS performance of studied companies. Subsequently, the weights of each criterion and sub-criterion of the proposed model were calculated to determine the most influent element on information system success.

\section{A. The AHP Method}

AHP is a multiple criteria decision making [4, 15]. It decomposes a complex MCDM problem into a system of hierarchies. The essential components are the main goal, the criteria that affect the overall goal, sub-criteria that influence the main criteria and finally the alternatives to the problem. A pairwise comparison matrix was developed using 1-9 preference scale [16] to obtain the degree of importance of element at each level, as shown in Table III. The procedure of the AHP involves the following steps [17-19]:

Step 1: Construct the structural hierarchy, this step is known as the AHP decision

Step 2: Construct the pairwise comparison matrix of attribute $i$ with attribute $j$ yield a square matrix $A_{n * n}$ where $a_{i j}$ denotes the comparative importance of attribute $i$ with respect to attribute $j$. In this matrix, $a_{i j}=1$ when $\mathrm{i}=\mathrm{j}$ and $a_{j i}=1 / a_{i j}$

$$
\mathrm{A}_{\mathrm{nn}}=\left[\begin{array}{ccc}
a_{11} & \cdots & a_{1 n} \\
\vdots & \ddots & \vdots \\
a_{n 1} & \cdots & a_{n n}
\end{array}\right]
$$

Step 3: Construct normalized decision matrix

$c_{i j}=a_{i j} / \sum_{j=1}^{n} a_{i j}$

$i=1,2,3, \ldots, n$ and $j=1,2,3, \ldots, n$

Step 4: Construct the weighted normalized decision matrix $w_{i}=\sum_{j=1}^{n} c_{i j} / n, i=1,2,3, \ldots, n$

$W=\left[\begin{array}{c}w_{1} \\ w_{2} \\ \cdots \\ w_{n}\end{array}\right]$

Step 5: Calculate eigenvector and row matrix
$\mathrm{E}=N^{t h}$ rootvalue $/ \sum N^{t h}$ rootvalue

Row matrix $=\sum_{j=1}^{n} a_{i j} * e_{j 1}$

Step 6: Calculate the maximum eigenvalue, $\lambda_{\max }$

$\lambda_{\max }=$ Rowmatrix $/ \mathrm{E}$

Step 7: Calculate the consistency index and consistency ratio

$$
\begin{aligned}
& \mathrm{CI}=\left(\lambda_{\text {max }}-\mathrm{n}\right) /(\mathrm{n}-1) \\
& \mathrm{CR}=\mathrm{CI} / \mathrm{RI}
\end{aligned}
$$

where $\mathrm{n}$ and RI denote the order of matrix and randomly generated consistency index respectively.

TABLE III. PAIRWISE COMPARISON SCALE

\begin{tabular}{|c|c|c|}
\hline Scale & Definition & Explanation \\
\hline $\mathbf{1}$ & Equal importance & $\begin{array}{c}\text { Two elements contribute equally to the } \\
\text { property }\end{array}$ \\
\hline $\mathbf{3}$ & $\begin{array}{c}\text { Moderate importance } \\
\text { of one over another }\end{array}$ & $\begin{array}{c}\text { Experience and judgment slightly } \\
\text { favor one over the other }\end{array}$ \\
\hline $\mathbf{5}$ & $\begin{array}{c}\text { Essential or strong } \\
\text { importance }\end{array}$ & $\begin{array}{c}\text { Experience and judgment strongly } \\
\text { favor one over another }\end{array}$ \\
\hline $\mathbf{7}$ & $\begin{array}{c}\text { Very strong } \\
\text { importance }\end{array}$ & $\begin{array}{c}\text { An element is strongly favored and its } \\
\text { dominance is demonstrated in practice } \\
\text { The evidence favoring one element } \\
\text { over another is one of the highest } \\
\text { possible order of affirmation }\end{array}$ \\
\hline $\mathbf{9}$ & Extreme importance & $\begin{array}{c}\text { Comprise is needed between two } \\
\text { judgments }\end{array}$ \\
\hline $\mathbf{6 , 8}$ & $\begin{array}{c}\text { between two adjacent } \\
\text { judgments }\end{array}$ & \begin{tabular}{c} 
Cormediate values \\
\hline
\end{tabular}
\end{tabular}

\section{WORK METHODOLOGY}

\section{A. Proposed Success Model}

In accordance with DeLone \& McLean [2, 5] and SERVQUAL [9] models, this work proposes an integrated model for assessing IS success. Consequently, six dimensions were proposed for measuring IS success: information quality, system quality, service quality, use, user satisfaction and net benefits. The model uses the SERVQUAL model to measure service quality using five dimensions: reliability, assurance, tangibles, empathy and responsiveness. (Figure 1)

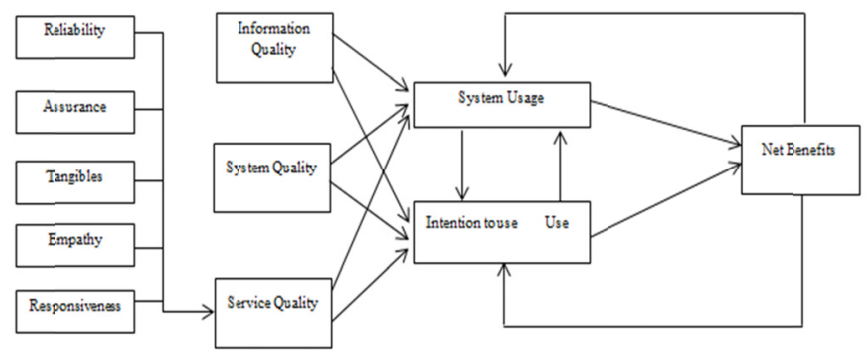

Fig. 1. Proposed success model

\section{B. Measurement of Variables}

We have chosen five specific items (sub-criteria) to measure each dimension (criteria) adapted from previous studies as follows: 


\section{1) System Quality}

The success criterion system quality constitutes the desirable characteristics of an IS. The measures (sub-criteria) of this criterion focus on studied system's performance. The selected system quality elements are: Access [20], ease of learning [21], flexibility [22], reliability [23] and response time $[22,23]$.

\section{2) Information Quality}

The success criterion information quality is an important factor relative to the characteristics of the information system's output. The selected information quality sub-criteria are: accuracy [24], completeness [22, 24], understandability [20], security [25], and usefulness [26].

\section{3) Service Quality}

The success criterion system quality represents the quality of the support that the IS offer to the users. The selected service quality elements are: reliability, assurance, tangibility, empathy and responsiveness [3].

\section{4) Intention to Use/Use}

The success criterion Intention to use/Use represents the manner of using an IS. The selected elements are: daily use [27], frequency of use [27], nature of use [2], number of site visits [2] and number of transactions [2].

\section{5) User Satisfaction}

The success criterion user satisfaction constitutes the user's level of satisfaction when using an IS. The selected user satisfaction elements are: adequacy [27], effectiveness [27], efficiency [27], enjoyment [20] and overall satisfaction [27].

\section{6) Nets Benefits}

This success criterion constitutes the extent to which IS is contributing to the success of different stakeholders, it subsumes the former separate individual and organizational impacts. The selected net benefits elements are: productivity [8], usefulness [8], competitive advantage [27], cost reduction [27] and overall success [27].

\section{Population and Sample}

A structured questionnaire was used for data collection, based on the proposed success model criteria and sub-criteria. A sample of 150 participants belonging to different sectors was chosen randomly based on their use of IS. Questionnaire development and returns were done by an online Google tool. The participants were asked to indicate their agreement with the influence of each criteria of IS success model. A five point Likert type scale was used with anchors from "Strongly agree" to "Strongly disagree". A total of 100 questionnaires were returned for a response rate of $67 \%$. Table IV shows the demographic characteristics of the received sample according to gender, age and experience.

\section{IMPLEMENTATION AND RESULTS}

\section{A. The Purpose of this Study}

The main purpose of this study is to present an IS success model guided by the updated DeLone \& McLean $[2,5]$ and
SERVQUAL [9] models. The proposed model composes six interrelated constructs of IS success measures: the quality dimension (system, information and service) which affects intention to use/use and user satisfaction. The net benefits dimension is a result of use and user satisfaction and could affect them. For our case, the quality service is measured by the SERVQUAL instrument. This study also aims to determine the critical and most dimension affecting IS success criteria. AHP, one of the most used MCDM techniques, was used to calculate the weights of each criterion and sub-criterion in order to determine the criterion most affecting IS success. The pairwise comparison matrix was developed according to the questionnaire responses. The criteria of our hierarchical model are the different dimensions of the model and the sub-criteria are the measures of each dimension chosen from previous studies (Table V).

TABLE IV. SAMPLE DISTRIBUTION

\begin{tabular}{|c|c|c|}
\hline \multicolumn{2}{|c|}{ Properties } & Percentage \\
\hline \multirow{2}{*}{ Gender } & Female & 29 \\
\cline { 2 - 3 } & Male & 71 \\
\hline \multirow{4}{*}{ Age (years) } & Less than 30 & 21.4 \\
\cline { 2 - 3 } & $30-39$ & 25 \\
\cline { 2 - 3 } & $40-50$ & 46.4 \\
\cline { 2 - 3 } & More than 50 & 7.2 \\
\hline \multirow{3}{*}{ Experience (years) } & Less than 5 & 16.1 \\
\cline { 2 - 3 } & 5-15 & 19.4 \\
\cline { 2 - 3 } & More than 15 & 64.5 \\
\hline
\end{tabular}

TABLE V. HIERARCHICAL CRITERIA PRESENTATION

\begin{tabular}{|c|c|}
\hline Main Criteria & Sub Criteria \\
\hline $\begin{array}{l}\text { System quality } \\
\left(\mathrm{C}_{1}\right)\end{array}$ & $\begin{array}{l}\text { Access }\left(C_{11}\right) \text {, ease of learning }\left(C_{12}\right) \text {, flexibility } \\
\left(C_{13}\right) \text {, reliability }\left(C_{14}\right) \text { and response time }\left(C_{15}\right)\end{array}$ \\
\hline $\begin{array}{l}\text { Information quality } \\
\qquad\left(\mathrm{C}_{2}\right)\end{array}$ & $\begin{array}{c}\text { Accuracy }\left(\mathrm{C}_{21}\right) \text {, completeness }\left(\mathrm{C}_{22}\right) \text {, } \\
\text { understandability }\left(\mathrm{C}_{23}\right) \text {, security }\left(\mathrm{C}_{24}\right) \text { and } \\
\text { usefulness }\left(\mathrm{C}_{25}\right)\end{array}$ \\
\hline $\begin{array}{l}\text { Service quality } \\
\left(\mathrm{C}_{3}\right)\end{array}$ & $\begin{array}{l}\text { Reliability }\left(\mathrm{C}_{31}\right) \text {, assurance }\left(\mathrm{C}_{32}\right) \text {, tangibility } \\
\left(\mathrm{C}_{33}\right) \text {, empathy }\left(\mathrm{C}_{34}\right) \text { and responsiveness }\left(\mathrm{C}_{35}\right)\end{array}$ \\
\hline Use $\left(\mathrm{C}_{4}\right)$ & $\begin{array}{c}\text { Dailey use }\left(\mathrm{C}_{41}\right) \text {, frequency of use }\left(\mathrm{C}_{42}\right) \text {, nature } \\
\text { of use }\left(\mathrm{C}_{43}\right) \text {, number of site visits }\left(\mathrm{C}_{44}\right) \text { and } \\
\text { number of transactions }\left(\mathrm{C}_{45}\right)\end{array}$ \\
\hline $\begin{array}{l}\text { User satisfaction } \\
\qquad\left(\mathrm{C}_{5}\right)\end{array}$ & $\begin{array}{l}\text { Adequacy }\left(\mathrm{C}_{51}\right) \text {, effectiveness }\left(\mathrm{C}_{52}\right) \text {, efficiency } \\
\left(\mathrm{C}_{53}\right) \text {, enjoyment }\left(\mathrm{C}_{54}\right) \text { and overall satisfaction } \\
\qquad\left(\mathrm{C}_{55}\right)\end{array}$ \\
\hline Net benefits $\left(\mathrm{C}_{6}\right)$ & $\begin{array}{c}\text { Productivity }\left(\mathrm{C}_{61}\right) \text {, usefulness }\left(\mathrm{C}_{62}\right) \text {, competitive } \\
\text { advantage }\left(\mathrm{C}_{63}\right) \text {, cost reduction }\left(\mathrm{C}_{64}\right) \text { and overall } \\
\text { success }\left(\mathrm{C}_{65}\right)\end{array}$ \\
\hline
\end{tabular}

TABLE VI. AGGREGATED PAIRWISE COMPARISON MATRIX

\begin{tabular}{|l|c|c|c|c|c|c|}
\hline & $\mathbf{C}_{\mathbf{1}}$ & $\mathbf{C}_{\mathbf{2}}$ & $\mathbf{C}_{\mathbf{3}}$ & $\mathbf{C}_{\mathbf{4}}$ & $\mathbf{C}_{\mathbf{5}}$ & $\mathbf{C}_{\mathbf{6}}$ \\
\hline $\mathbf{C}_{\mathbf{1}}$ & 1 & 3 & 5 & 7 & 3 & 5 \\
\hline $\mathbf{C}_{\mathbf{2}}$ & 0.33 & 1 & 3 & 5 & 3 & 5 \\
\hline $\mathbf{C}_{\mathbf{3}}$ & 0.2 & 0.33 & 1 & 3 & 5 & 7 \\
\hline $\mathbf{C}_{\mathbf{4}}$ & 0.14 & 0.2 & 0.33 & 1 & 3 & 5 \\
\hline $\mathbf{C}_{\mathbf{5}}$ & 0.33 & 0.33 & 0.2 & 0.33 & 1 & 5 \\
\hline $\mathbf{C}_{\mathbf{6}}$ & 0.2 & 0.2 & 0.14 & 0.2 & 0.2 & 1 \\
\hline
\end{tabular}

\section{B. Implementation}

After developing the proposed model, our objective is to select the most influential criterion on IS success. The hierarchical model contains 6 criteria and 30 sub-criteria as 
shown in Table VII. The weights of the main criteria and subcriteria are estimated using AHP method and the data collection are collected by an online questionnaire. A pairwise comparison matrix of criteria (Table VI) and the calculation of the weights are given. A normalized matrix $\mathrm{C}$ has been calculated using (1).

TABLE VII. NORMALIZED DECISION MATRIX

\begin{tabular}{|l|c|c|c|c|c|c|}
\hline & $\mathbf{C}_{\mathbf{1}}$ & $\mathbf{C}_{\mathbf{2}}$ & $\mathbf{C}_{\mathbf{3}}$ & $\mathbf{C}_{\mathbf{4}}$ & $\mathbf{C}_{\mathbf{5}}$ & $\mathbf{C}_{\mathbf{6}}$ \\
\hline $\mathbf{C}_{\mathbf{1}}$ & 0.45 & 0.59 & 0.52 & 0.42 & 0.20 & 0.18 \\
\hline $\mathbf{C}_{\mathbf{2}}$ & 0.15 & 0.20 & 0.31 & 0.30 & 0.20 & 0.18 \\
\hline $\mathbf{C}_{\mathbf{3}}$ & 0.09 & 0.06 & 0.10 & 0.18 & 0.33 & 0.25 \\
\hline $\mathbf{C}_{\mathbf{4}}$ & 0.06 & 0.04 & 0.03 & 0.06 & 0.20 & 0.18 \\
\hline $\mathbf{C}_{\mathbf{5}}$ & 0.15 & 0.06 & 0.02 & 0.02 & 0.07 & 0.18 \\
\hline $\mathbf{C}_{\mathbf{6}}$ & 0.09 & 0.04 & 0.01 & 0.01 & 0.01 & 0.04 \\
\hline
\end{tabular}

Then the priority weights are calculated using (2):

$$
\begin{aligned}
& \mathrm{w}_{1}=2.364 / 6=0.39 \mathrm{w}_{2}=1.336 / 6=0.22 \\
& \mathrm{w}_{3}=1.012 / 6=0.17 \mathrm{w}_{4}=0.574 / 6=0.1 \\
& \mathrm{w}_{5}=0.500 / 6=0.08 \mathrm{w}_{6}=0.206 / 6=0.03
\end{aligned}
$$

The normalized weight vector of main criteria is $\mathrm{W}=(0.39$, $0.22,0.17,0.1,0.08,0.03)$, the most valuable criteria with priority of 0.39 is $\mathrm{C}_{1}$ "System Quality". The same computational way is anticipated to determine the weights of sub-criteria presented in Table VIII. To calculate $\lambda_{\max }$, we used (4), (5), and (6): $\lambda_{\max }=6.08$. Consistency index (CI) and consistency ratio (CR) are calculated through (7) and (8) respectively (for $\mathrm{RI}=1.24$ ): $\mathrm{CI}=0.016$ and $\mathrm{CR}=0.012$. As the value of CR (0.012) is less than 0.10 , it is accepted.

TABLE VIII. SUB-CRITERIA WEIGHTS

\begin{tabular}{|c|c|c|c|}
\hline Sub-Criteria & Weight & Sub-Criteria & Weight \\
\hline$C_{11}$ & 0.42 & $C_{41}$ & 0.42 \\
\hline$C_{12}$ & 0.26 & $C_{42}$ & 0.23 \\
\hline$C_{13}$ & 0.15 & $C_{43}$ & 0.15 \\
\hline$C_{14}$ & 0.11 & $C_{44}$ & 0.12 \\
\hline$C_{15}$ & 0.06 & $C_{45}$ & 0.07 \\
\hline$C_{21}$ & 0.34 & $C_{51}$ & 0.45 \\
\hline$C_{22}$ & 0.25 & $C_{52}$ & 0.24 \\
\hline$C_{23}$ & 0.19 & $C_{53}$ & 0.15 \\
\hline$C_{24}$ & 0.15 & $C_{54}$ & 0.11 \\
\hline$C_{25}$ & 0.06 & $C_{55}$ & 0.04 \\
\hline$C_{31}$ & 0.37 & $C_{61}$ & 0.46 \\
\hline$C_{32}$ & 0.25 & $C_{62}$ & 0.21 \\
\hline$C_{33}$ & 0.15 & $C_{63}$ & 0.19 \\
\hline$C_{34}$ & 0.13 & $C_{64}$ & 0.09 \\
\hline$C_{35}$ & 0.11 & $C_{65}$ & 0.04 \\
\hline
\end{tabular}

\section{Survey Results}

AHP method was used to determine the weights of each criterion of the proposed model. The results show that the system quality dimension has a weight equal to 0.39 which is the higher value, it means that the most influential criterion on information system success is it system quality. The results indicate that system quality has a strong significant influence on information system success $(0.39)$ followed by information quality (0.22), service quality (0.17), intention to use /use $(0.10)$, user satisfaction $(0.08)$ and net benefits $(0.03)$. Figure 3 shows the weights of each dimension. The results show also that service quality exhibited a stronger effect on IS success, specially the degree of service reliability $(0.37)$. To obtain these results, as we already mentioned that a questionnaire was distributed and the aggregated pairwise comparison matrix was developed according to the questionnaire results. Table IX shows the degree of influence of each criterion on IS success

\begin{tabular}{|c|c|c|c|c|c|c|}
\hline Dimension & 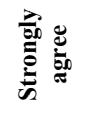 & 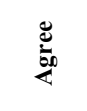 & 密 & 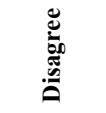 & 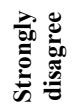 & 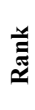 \\
\hline $\begin{array}{l}\text { System } \\
\text { Quality }\end{array}$ & $56.7 \%$ & $27.4 \%$ & $9 \%$ & $5 \%$ & $2 \%$ & 1 \\
\hline $\begin{array}{c}\text { Information } \\
\text { Quality }\end{array}$ & $55.8 \%$ & $23.4 \%$ & $11.5 \%$ & $5.3 \%$ & $4 \%$ & 2 \\
\hline $\begin{array}{l}\text { Service } \\
\text { Quality }\end{array}$ & $50 \%$ & $21.4 \%$ & $13.70 \%$ & $8.6 \%$ & $6.3 \%$ & 3 \\
\hline $\begin{array}{c}\text { Intention to } \\
\text { use/Use }\end{array}$ & $48.2 \%$ & $19.8 \%$ & $13.80 \%$ & $10.40 \%$ & $7.8 \%$ & 4 \\
\hline $\begin{array}{c}\text { User } \\
\text { Satisfaction }\end{array}$ & $40.6 \%$ & $31.7 \%$ & $14.4 \%$ & $10.3 \%$ & $3 \%$ & 5 \\
\hline Net Benefits & $35 \%$ & $34.2 \%$ & $12.80 \%$ & $10 \%$ & $8 \%$ & 6 \\
\hline
\end{tabular}
from the participants' point of view.

TABLE IX. SURVEY RESULTS

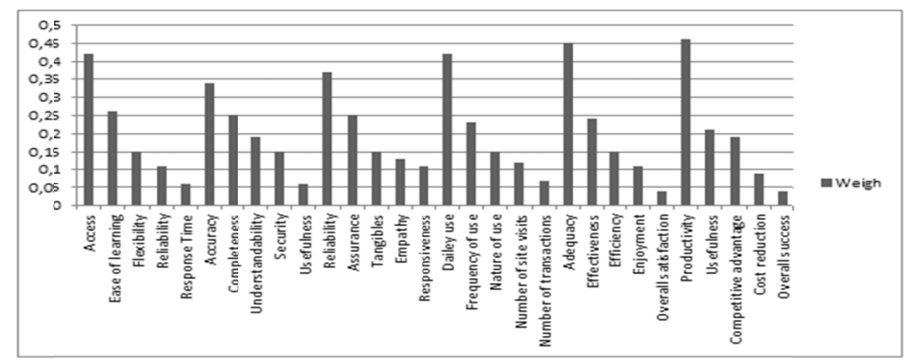

Fig. 2. Elements' importance

\section{CONCLUSION}

This study proposed an IS model based on the Delone and McLean IS success model and the SERVQUAL model to evaluate service quality. The analysis results indicated that system quality has a strong significant influence on IS success. Thus, system developers should focus more on access, ease of learning, flexibility, reliability and system response time. System developers should fully exploit accuracy, completeness, understandability, security and usefulness of information. Finally, the proposed success model and its dimensions can be used as a tool in organizations to evaluate their information systems.

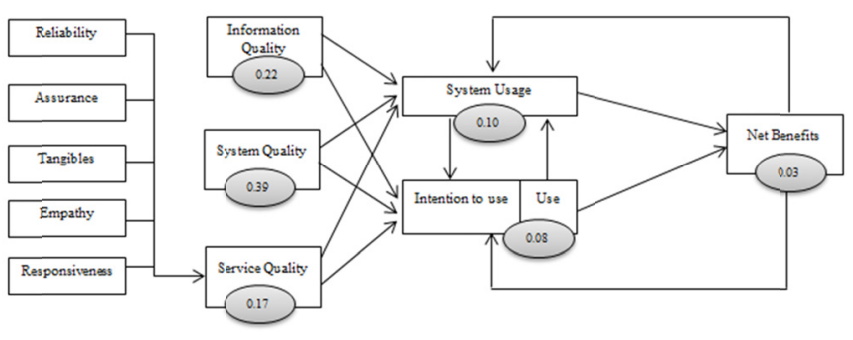

Fig. 3. Weights of criteria 


\section{REFERENCES}

[1] A. Carugati, C. Rossignoli, Emerging Themes in Information Systems and Organization Studies, Psysica Verlag, 2011

[2] W. H. DeLone, E. R. McLean, "The Delone and McLean Model of Information Systems Success: a Ten-Year Update", Journal of Management Information Systems, Vol. 19, No. 4, pp. 9-30, 2003

[3] A. Parasuraman, V. Ziethaml, L. L. Berry, "SERVQUAL: A MultipleItem Scale for Measuring Consumer Perceptions of Service Quality", Journal of Retailing, Vol. 62, No. 1, pp. 12-40, 1988

[4] T. L. Saaty, The analytic hierarchy process, McGraw-Hill, 1980

[5] W. H. DeLone, E. R. McLean, "Information Systems Success: The Quest for the Dependent Variable", Information Systems Research, Vol. 3, No. 1, pp. 60-95, 1992

[6] L. F. Pitt, R. T. Watson, C. B. Kavan, "Service Quality: a Measure of Information Systems effectiveness”, MIS Quarterly, Vol. 19, No. 2, pp. 173-187, 1995

[7] M. A. Fishbein, I. Ajzen, Belief, Attitude, Intention and Behavior: an Introduction to Theory and Research, Addison Wesley, 1975

[8] F. D. Davis, "Perceived Usefulness, Perceived Ease of Use, and User Acceptance of Information Technology", MIS Quarterly, Vol. 13, No. 3, pp. 319-340, 1989

[9] A. Parasuraman, V. A. Zeithaml, L. L. Berry, "A conceptual model of service quality and its implications for future research", Journal of Marketing, Vol. 49, No. 4, pp. 41-50, 1985

[10] F. Buttle, "SERVQUAL: review, critique, research agenda", European Journal of Marketing, Vol. 30, No. 1, pp. 8-32, 1996

[11] N. H. Zardari, K. Ahmed, S. M. Shirazi, Z. B. Yusop, Weighting Methods and their Effects on Multi-Croteria Decision Making Model Outcomes in Water Ressources Management, Springer, 2015

[12] F. A. Lootsma, Multi-criteria decision analysis via ratio and difference judgement, Kluwer Academic Publishers, 1999

[13] J. Fulop, "Introduction to Decision Making Methods", Working Paper 05-6, Laboratory of Operations Research and Decision Systems, Computer and Automation Institute, Hungarian Academy of Sciences, Budapest, 2005

[14] V. Podvezko, "The Comparative Analysis of MCDA Methods SAW and COPRAS”, Inzinerine Ekonomika-Engineering Economics, Vol. 22, No. 2, pp. 134-146, 2011

[15] T. L. Saaty, K. Penivati, Group decision making: Drawing out and reconciling Differences.: RWS Publications, Pittsburgh, USA, 2008

[16] T. L. Saaty, "Ran6k from Comparisons and From Ratings in the Analytic Hierarchy/Network Process", European Journal of Operational Research, Vol. 168, No. 2, pp. 557-570, 2009

[17] T. L. Saaty, "Decision making with the analytic hierarchy process", International Journal of Services Sciences, Vol. 1, No. 1, pp. 83-98, 2008

[18] A. H. I. Lee, W. C. Chen, C. J. Chang, "A fuzzy AHP and BSC approach for evaluating performance of IT department in the manufacturing industry in Taiwan", Expert Systems with Applications, Vol. 34, No. 1, pp. 96-107, 2008

[19] M. Dagdeviren, S. Yavuz, N. Kilinc, "Weapon selection using the AHP and TOPSIS methods under fuzzy environment", Expert Systems with Applications, Vol. 36, No. 4, pp. 8143-8151, 2009

[20] G. G. Gable, D. Sedera, T. Chan, "Re-conceptualizing Information System Success: The IS-Impact Measurement Model", Journal of Association for Information Systems, Vol. 9, No. 7, pp. 377-408, 2008

[21] D. Sedera, G. G. Gable, "A Factor and Structural Equation Analysis of the Enterprise Systems Success Measurement Model", 25th International Conference on Information Systems, Washington DC, pp. 449-463, December 12-15, 2004

[22] J. Iivari, "An empirical test of the Delone-Mclean model of information system success", The DATA BASE for Advances in Information Systems, Vol. 36, No. 2, pp. 8-27, 2005

[23] S. Hamilton, N. L. Chervany, "Evaluating information system effectiveness - part I: Comparing evaluation approaches", MIS Quarterly, Vol. 5, No. 3, pp. 55-69, 1981
[24] J. E. Bailey, S. W. Pearson, "Development of a tool for measuring and analyzing computer user satisfaction", Management Science, Vol. 29 No. 5, pp. 530-545, 1983

[25] S. Knight, J. Burn, "Developing a Framework for Assessing Information Quality on the World Wide Web", Informing Science Journal, Vol. 8, pp. 159-172, 2005

[26] V. McKinney, Y. Kanghyun, F. M. Zahedi, "The measurement of webcustomer satisfaction: An expectation and disconfirmation approach", Information Systems Research, Vol. 13, No. 3, pp. 296-315, 2002

[27] H. Almutairi, G. H. Subramanian, "An empirical application of the Delone and Mclean model in the Kuwaiti private sector", Journal of Computer Information Systems, Vol. 45, No. 3, pp. 113-122, 2005 